\title{
Hubungan Usia, Jenis Kelamin, Pendidikan Orangtua, Status Sosioekonomi Keluarga, dan Dosis Kumulatif Prednison dengan Masalah Psikososial Pasien Sindrom Nefrotik Idiopatik
}

\author{
Mahesa Suryanagara, Dedi Rachmadi, Budi Setiabudiawan \\ Departemen Ilmu Kesehatan Anak Fakultas Kedokteran Universitas Padjadjaran/Rumah Sakit Umum \\ Pusat Dr. Hasan Sadikin, Bandung
}

\begin{abstract}
Latar belakang. Sindrom nefrotik idiopatik (SNI) merupakan penyakit kronik yang memerlukan pengobatan steroid jangka panjang. Pada penyakit kronik lain telah diteliti pemberian steroid jangka panjang dan faktor yang berpengaruh terhadap terjadinya masalah psikososial.

Tujuan. Menganalisis hubungan faktor usia, jenis kelamin, tingkat pendidikan orangtua, status sosioekonomi, dan dosis kumulatif prednison dengan terjadinya masalah psikososial.

Metode. Penelitian cross sectional dilaksanakan dari Januari 2013 sampai Mei 2013 melibatkan 26 subjek. Masalah psikososial dinilai dengan kuesioner Pediatric Symptom Checklist (PSC)-17. Analisis statistik dengan uji chi-square dan regresi logistik ganda.

Hasil. Terdapat 13 dari 26 subjek mengalami masalah psikososial. Hasil analisis bivariabel mendapatkan usia 10-14 tahun RP 2,56 (IK95\% 1,16-5,64); p=0,016, jenis kelamin perempuan RP 2,86 (IK 95\% 1,02-8,04); $\mathrm{p}=\mathbf{0 , 0 1 6}$, pendidikan dasar orangtua RP 3,60 (IK 95\% 1,50-8,62); p=0,004, status sosioekonomi keluarga rendah RP 1,25 (IK95\% 0,54-2,89); p=0,001, dan dosis kumulatif prednison $\geq 3.640 \mathrm{mg}$ RP 4,714 (IK 95\% 1,292-17,201); $\mathrm{p}=0$,002. Analisis multivariabel didapatkan usia RP 25,17 (IK95\% 1,01-629,71);

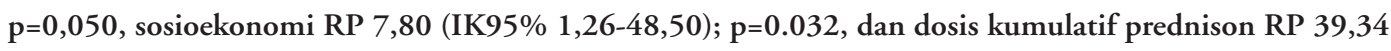
(IK 95\% 1,89-818,93); p=0,018.

Kesimpulan. Faktor usia, jenis kelamin, tingkat pendidikan orangtua, status sosioekonomi, dan dosis kumulatif prednison berhubungan dengan masalah psikososial pasien SNI. Dosis kumulatif prednison merupakan faktor paling dominan terhadap terjadinya masalah psikososial pasien SNI.
\end{abstract}

Sari Pediatri 2014;15(6):415-9.

Kata kunci: masalah psikososial, prednison, sindrom nefrotik idiopatik

\footnotetext{
Alamat korespondensi:

Dr. Dedi Rachmadi dr., Sp.A(K), M.Kes. Departemen Ilmu Kesehatan Anak Fakultas Kedokteran Universitas Padjadjaran/Rumah Sakit Dr. Hasan Sadikin. Jl. Pasteur No. 38 Bandung 40163. Telp. (022) 2035957.

E-mail: dedirachmadi@yahoo.com
}

indrom nefrotik idiopatik (SNI) adalah kumpulan keadaan klinis yang ditandai dengan edema, proteinuria, dan hipoalbuminemia dengan atau tanpa hiperkole- 
sterolemia. ${ }^{1-3}$ Relaps akan dialami $60 \%-70 \%$ pasien SNI dan setengah di antaranya berupa relaps sering atau dependen steroid sehingga penyakit akan berjalan kronik, ${ }^{4-5}$ dan pemberian steroid akan semakin sering. Pemberian steroid yang lama dengan dosis tinggi dapat menyebabkan kerusakan hipokampus yang merupakan organ pengaturan perilaku, memengaruhi suasana hati, tingkah laku, dan memori sehingga pada akhirnya akan menimbulkan dampak berupa gangguan psikososial.6,7 Faktor usia, jenis kelamin, pendidikan orangtua, dan status sosioekonomi keluarga mempunyai pengaruh dengan terjadinya masalah psikososial pada pasien penyakit kronik. 4,6 Masalah psikososial dapat dinilai dengan menggunakan kuesioner Pediatric Symptom Checklist (PSC)-17 yang aplikatif dan praktis karena hanya memerlukan waktu kurang lebih 7 menit untuk penggunaannya dengan sensitivitas dan spesifisitas yang tinggi. ${ }^{8,9}$

Sampai saat ini, belum ada penelitian atau data mengenai hubungan berbagai faktor yaitu usia, jenis kelamin, pendidikan orangtua, status sosioekonomi keluarga, dan dosis kumulatif prednison dengan terjadinya masalah psikososial yang diteliti secara bersama pada pasien SNI.

Tujuan dari penelitian ini untuk mengetahui hubungan faktor usia, jenis kelamin, pendidikan orangtua, status sosioekonomi keluarga, dan dosis kumulatif prednison dengan terjadinya masalah psikososial pada pasien SNI dan menilai faktor yang paling dominan dalam menyebabkan masalah psikososial pada pasien SNI.

\section{Metode}

Penelitian desain observasional potong silang dilakukan pada periode Januari 2013 sampai dengan Mei 2013. Kriteria inklusi sampel adalah anak pasien SNI berusia antara 4-14 tahun, telah mengalami penyakit selama 3 bulan, memiliki catatan medis lengkap, termasuk latar belakang pendidikan orangtua, pendapatan orangtua sebulan dan jumlah prednison yang diberikan. Kriteria eksklusi adalah mempunyai penyakit kronis selain SNI, seperti tuberkulosis paru, penyakit jantung bawaan, asma bronkial, hemofilia, talasemia dan keganasan. Duapuluh enam anak pasien SNI dilibatkan dalam penelitian di RSUP Dr. Hasan Sadikin Bandung serta RS jejaring (RSUD Cibabat dan RSUD Kota Bandung).
Sampel diambil secara consecutive sampling yang datang ke poliklinik anak atau yang dirawat inap sampai ukuran sampel terpenuhi. Data diperoleh melalui anamnesis, pemeriksaan fisis, dan pengisian kuesioner PSC-17.

Alat penilaian yang digunakan untuk menilai masalah psikososial adalah PSC-17. Alat penilaian ini digunakan untuk usia 4-16 tahun, yang terdiri dari pertanyaan subskala internalisasi (5 pertanyaan), subskala eksternalisasi (7 pertanyaan), dan subskala perhatian (5 pertanyaan), sehingga jumlah seluruh pertanyaan 17 . Masing-masing pertanyaan memiliki nilai 0-2 untuk jawaban tidak pernah (nilai 0), kadangkadang (nilai 1), dan selalu (nilai 2). Dicurigai masalah psikososial, jika jumlah nilai internalisasi $\geq 5$, jumlah nilai eksternalisasi $\geq 7$, dan jumlah nilai perhatian $\geq 7$, atau nilai total $\geq 15$ (internalisasi + eksternalisasi + perhatian). Penelitian telah mendapat persetujuan Komite Etik Penelitian Kesehatan Fakultas Kedokteran Universitas Padjadjaran/RS Hasan Sadikin Bandung.

Analisis bivariabel digunakan untuk melihat hubungan antara variabel independen (usia, jenis kelamin, pendidikan orangtua, status sosioekonomi keluarga, dan dosis kumulatif prednison) dengan variabel dependen (masalah psikososial) dengan menggunakan uji chi-square dengan tingkat kemaknaan $\mathrm{p}<0,05$. Keeratan hubungan antar variabel digunakan rumus rasio prevalensi (RP).

Rasio prevalensi $<1$ terdiri dari usia, jenis kelamin, pendidikan orangtua, status sosioekonomi keluarga, dan dosis kumulatif prednison mempunyai hubungan dengan masalah psikososial. Rasio prevalensi $\geq 1$ terdiri dari usia, jenis kelamin, pendidikan orangtua, status sosioekonomi keluarga, dan dosis kumulatif prednison tidak berhubungan dengan masalah psikososial. Faktor yang paling dominan dilihat dengan analisis multivariabel regresi logistik ganda. Analisis data digunakan piranti lunak SPSS versi 20 (Windows).

\section{Hasil}

Hasil analisis bivariabel untuk menilai hubungan variabel dengan masalah psikososial tertera pada Tabel 1 , sedangkan jumlah dosis kumulatif prednison yang diterima pasien SNI tertera pada Tabel 2.

Analisis bivariabel menunjukkan bahwa usia remaja 10-14 tahun, jenis kelamin perempuan, pendidikan dasar orangtua, status sosial ekonomi rendah, dan dosis kumulatif prednison $\geq 3640$ mg berhubungan dengan terjadinya masalah psikososial. 
Mahesa Suryanagara dkk: Hubungan usia, jenis kelamin, pendidikan orangtua, status sosioekonomi, dan dosis kumulatif prednison dengan masalah psikososial pasien SNI

Tabel 1. Analisis bivariabel hubungan berbagai variabel dengan masalah psikososial

\begin{tabular}{|c|c|c|c|c|c|}
\hline \multirow{2}{*}{ Variabel } & \multicolumn{2}{|c|}{ Masalah psikososial } & \multirow[b]{2}{*}{$\mathrm{p}$} & \multirow{2}{*}{$\mathrm{RP}$} & \multirow{2}{*}{ IK95\% } \\
\hline & $\mathrm{Ya}(+)$ & Tidak (-) & & & \\
\hline \multicolumn{6}{|l|}{ Usia (tahun) } \\
\hline $4-9$ & 5 & 11 & 0,016 & 1 & \\
\hline $10-14$ & 8 & 2 & & 2,56 & $1,16-5,64$ \\
\hline \multicolumn{6}{|l|}{ Jenis kelamin } \\
\hline Perempuan & 10 & 4 & 0,018 & 2,86 & $1,02-8,04$ \\
\hline Laki-laki & 3 & 9 & & 1 & \\
\hline \multicolumn{6}{|l|}{ Pendidikan orangtua } \\
\hline Dasar & 9 & 1 & 0,004 & 3,60 & $1,50-8,62$ \\
\hline Menengah + tinggi & 4 & 12 & & 1 & \\
\hline \multicolumn{6}{|c|}{ Status sosial ekonomi keluarga } \\
\hline Rendah & 10 & 2 & 0,001 & 1,25 & $0,54-2,89$ \\
\hline Sedang & 1 & 10 & & 0,14 & $0,02-1,00$ \\
\hline Tinggi & 2 & 1 & & 1 & \\
\hline \multicolumn{6}{|c|}{ Dosis kumulatif prednison (ROC) } \\
\hline$>3640 \mathrm{mg}$ & 11 & 3 & & 4,714 & $1,292-17,201$ \\
\hline$<3640 \mathrm{mg}$ & 2 & 10 & 0,002 & 1 & \\
\hline
\end{tabular}

Tabel 2. Dosis kumulatif prednison yang diterima pasien SNI

\begin{tabular}{lc}
\hline Dosis kumulatif prednison & $\mathrm{N}$ \\
\hline $2000-10880,5$ & 23 \\
$10881-19761,5$ & 2 \\
$19762-28642,5$ & 0 \\
$28643-37524$ & 1 \\
\hline
\end{tabular}

Keterangan: ${ }^{*}$ ) dosis $3.640 \mathrm{mg}$ adalah sebagai dosiscut-off pointyang diperoleh melalui kurva ROC

Berdasarkan dosis kumulatif prednison yang diterima oleh subjek, 23 mendapatkan dosis kumulatif prednison berkisar antara 2000 sampai $10880,5 \mathrm{mg}$ dan dosis $3640 \mathrm{mg}$ adalah titik potong dalam kurva receiver operating characteristics curve (ROC) dengan tingkat akurasi tertinggi $80,8 \%$ dan area under the curve $86,4 \%$ tertera pada Gambar 1 .

Untuk menentukan seberapa besar hubungan variabel tersebut berperan terhadap terjadinya masalah psikososial secara simultan, maka dilakukan analisis menggunakan regresi logistik (Tabel 3). Terlihat bahwa dosis kumulatif prednison merupakan faktor yang paling dominan menyebabkan masalah psikososial pada pasien SNI.

\section{Pembahasan}

Hasil penelitian kami mendapatkan masalah psikososial pada 13 dari 26 subjek (50\%) yang menderita sindrom nefrotik idiopatik, penelitian di India

Tabel 3. Analisis multivariabel hubungan berbagai variabel dengan masalah psikososial dengan regresi logistik ganda (model akhir)

\begin{tabular}{lccc}
\hline Variabel & Odd ratio & $\begin{array}{c}\text { Rasio prevalensi } \\
\text { (IK 95\%) }\end{array}$ & $\mathrm{p}$ \\
\hline Usia & 25,17 & $25,17(1,01-629,71)$ & 0,050 \\
Sosioekonomi & 7,80 & $7,80(1,26-48,50)$ & 0,032 \\
Dosis kumulatif prednison & 39,34 & $39,34(1,89-818,93)$ & 0,018 \\
Konstanta & - & - & - \\
\hline
\end{tabular}

Keterangan: Akurasi model = 88,5\% 


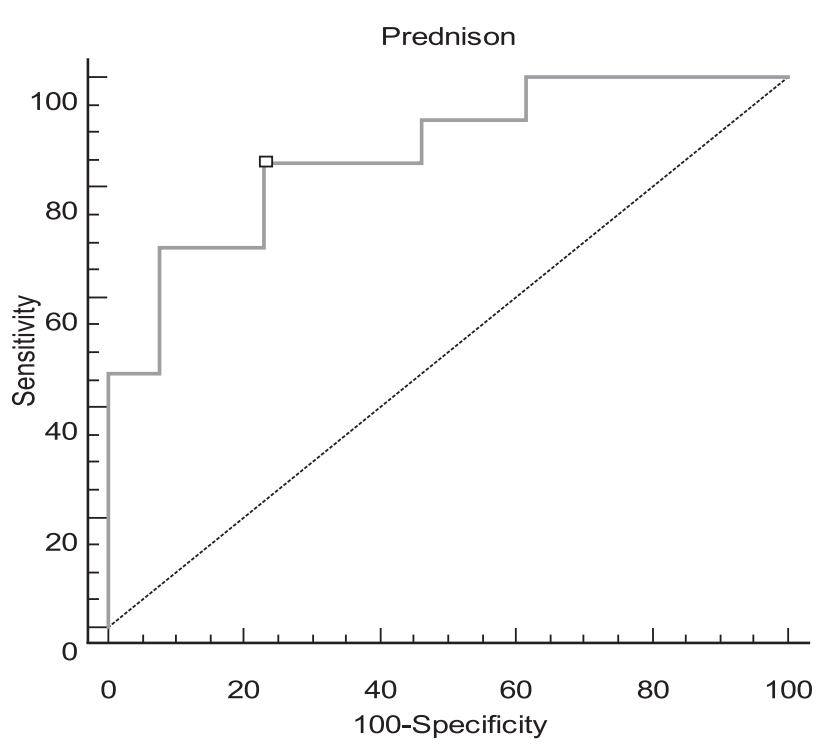

Gambar 1. Cut-off point dosis kumulatif prednison (berdasarkan kurva ROC).

mendapatkan $68 \%,{ }^{6}$ dan di Inggris 33\%. ${ }^{10}$ Hasil yang berbeda disebabkan desain penelitian, termasuk alat penilaian psikososial yang digunakan, dan etnik yang berbeda. Penelitian yang menguji adanya hubungan berbagai faktor yang diduga berpengaruh terhadap terjadinya masalah psikososial, seperti usia, jenis kelamin, pendidikan orangtua, status sosioekonomi keluarga serta dosis kumulatif prednison yang dianalisis secara bersama masih sangat sedikit. Penelitian yang sudah ada menggunakan kuesioner Child Behavior Checklist yang lebih kompleks dan tidak praktis, ${ }^{6,10}$ sedangkan penelitian kami menggunakan kuesioner PSC-17 yang lebih praktis.

Pada penelitian kami, seluruh faktor yang diduga berpengaruh terhadap terjadinya masalah psikososial pada pasien SNI dianalisis untuk mengetahui adanya hubungan dicari faktor manakah yang paling dominan terhadap kejadian masalah psikososial dibandingkan faktor yang lain. Dosis kumulatif prednison $>3$ $640 \mathrm{mg}$ dengan odd ratio 39,34 merupakan faktor yang paling dominan terhadap terjadinya masalah psikososial dibandingkan faktor yang lain. Hasil tersebut disebabkan karena paparan kortikosteroid berpengaruh pada perubahan morfologi hipokampus yang mempunyai fungsi dalam pengaturan perilaku emosional. ${ }^{11,12}$ Kortikosteroid menyebabkan potensi pelepasan dan penghambatan re-uptake glutamat, peningkatan ekspresi reseptor $N$-methyl Daspartic Acid (NMDA), penurunan inhibisi Gamma Amino
Butyric Acid (GABA)-ergic, sedangkan glutamat yang diperantarai aktivasi reseptor NMDA tanpa disertai inhibisi GABA yang memadai serta potensi serotonin menyebabkan influks kalsium ke dalam sel neuron. Konsentrasi kalsium intraselular yang tinggi kemudian dapat menyebabkan depolimerisasi sitoskeleton, otolisis, dan kematian sel neuron. ${ }^{13}$

Remaja berusia 10-14 tahun merupakan faktor dominan kedua setelah dosis kumulatif prednison yang berhubungan dengan terjadinya masalah psikososial. Hal tersebut sesuai dengan penelitian sebelumnya yang menjelaskan bahwa masalah psikososial pada pasien penyakit kronik terjadi terutama pada saat usia remaja karena merupakan periode transisi secara emosional, sosial, agama, dan hubungan keluarga. ${ }^{14}$ Sosial ekonomi rendah merupakan faktor dominan ketiga yang berhubungan dengan terjadinya masalah psikososial pada penelitian kami. Sesuai dengan penelitian yang dilakukan di India yang memperlihatkan bahwa status sosial ekonomi keluarga berhubungan dengan keberhasilan pengobatan yang ditentukan oleh kepatuhan dan keteraturan dalam berobat. ${ }^{6}$

Jenis kelamin perempuan dan pendidikan dasar orangtua tidak berhubungan dengan terjadinya masalah psikososial pada pasien SNI. Berbeda dengan penelitian sebelumnya yang menyatakan perempuan lebih besar berisiko mendapatkan masalah psikososial pada penyakit kronis dibandingkan laki-laki. ${ }^{14}$ Begitu juga dengan tingkat pendidikan orangtua rendah tidak berperan terhadap masalah psikososial pasien SNI. Hasil tersebut juga berbeda dengan penelitian sebelumnya yang menyatakan bahwa terdapat peran faktor pendidikan orangtua yang rendah terhadap terjadinya masalah psikososial. ${ }^{10}$ Perbedaan hasil penelitian ini dengan sebelumnya disebabkan karena beberapa kemungkinan, di antaranya desain penelitian, termasuk alat penilaian psikososial, dan etnik yang berbeda.

Keterbatasan penelitian kami, yaitu pengambilan sampel hanya dilakukan pada satu waktu saja sehingga faktor keluarga tidak dilihat secara menyeluruh, seperti tidak dilakukan evaluasi dengan penilaian standar untuk mengetahui adanya gangguan kejiwaan pada orangtua atau keluarga lainnya. Kondisi lingkungan di sekitar pasien juga tidak diperhatikan secara mendalam, seperti dukungan dari lingkungan, yaitu guru, kelompok sebaya (peer group), dan keluarga karena faktor-faktor tersebut mempunyai peran positif terhadap tumbuh kembang anak dengan penyakit kronik. 


\section{Kesimpulan}

Terdapat hubungan antara usia remaja, jenis kelamin perempuan, tingkat pendidikan orang tua rendah, status sosio ekonomi rendah dan dosis kumulatif prednison $\geq 3640 \mathrm{mg}$ terhadap terjadinya masalah psikososial pada pasien SNI. Dosis kumulatif prednison $\geq 3640 \mathrm{mg}$ merupakan faktor paling dominan terhadap terjadinya masalah psikososial pada anak yang menderita SNI.

\section{Daftar pustaka}

1. Haycock G. The child with idiopathic nephrotic syndrome. Dalam: Webb N, Postlethwaite R, penyunting. Clinical pediatric nephrology. Edisi ke-3. New York: Oxford; 2003.h.341-66.

2. UKK Nefrologi IDAI. Konsensus tatalaksana sindrom nefrotik idiopatik pada anak. Edisi ke-2. Jakarta: BP IDAI; 2008.

3. Vogt BA, Avner ED. Nephrotic syndrome. Dalam: Behrman RE, Kliegman RM, Jenson HB penyunting. Nelson Textbook of Pediatrics. Edisi ke 17. Philadelphia: Saunders; 2009.h.1753-7.

4. Bagga A, Mantan M. Nephrotic syndrome in children. Indian J Med Res 2005;122:13-28.

5. Niaudet P. Long term outcome of children with steroid sensitive idiophatic nephrotic syndrome. Clin J Am Soc nephrol 2009;4:1547-8.
6. Guha P, De A, Ghosal M. Behavior profile of children with nephrotic syndrome. Indian J Psychiatri 2009;51:122-6.

7. Neuhaus T, Langlois V, Licht C. Behavioural abnormalities in children with nephrotic syndrome-an underappreciated complication of a standard treatment. Nephrol Dial Transplant 2010;25:2397-9.

8. Borowsky IW, Mozayeny S, Ireland M. Brief psychosocial screening at health supervision and acute care visits. Pediatrics 2003;112:129-33.

9. Jellinek M, Murphy JM, Psychosocial problems, screening, and the pediatric symptom checklist. (C) 1999 dbpeds.org [diunduhJuni 12 2012]. Didapat dari: http:// www/dbpeds.org/handouts.

10. Hall A, Thorley G, Houtman P. The effects of corticosteroid on behavior in children with nephritoc syndrome. Pediatr Nephrol 2003;18:1220-3.

11. Duvernoy H, Cattin F, Fatterpekar G, Naidich T, Raybaud C, Risold P. The human hippocampus. Berlin: Springer;2005.h.5-38.

12. Groeneweg FL, Kars H, DeKloet ER, Joels M. Rapid non-genomic effects of corticosteroids and their role in central stress response. J Endocrinology 2011;209:15367.

13. De Kloet ER, Vreugdenhil E, Oitzl M, Joels M. Brain corticosteroid receptor balance in health and disease. Endocrine Rev 1998;19:269-301.

14. Mehta M, Bagga A, Pande P, Bajaj C, Srivastava R. Behavior problem in nephrotic syndrome. Indian Pediatri 1995;32:1281-6. 